\title{
Toulouse « Tolosa »
}

Jardin de la basilique Saint-Sernin

\section{Christine Dieulafait}

\section{(2) OpenEdition}

12 Journals

Édition électronique

URL : http://journals.openedition.org/adlfi/10957

ISSN : 2114-0502

Éditeur

Ministère de la culture

Référence électronique

Christine Dieulafait, «Toulouse «Tolosa » , ADLFI. Archéologie de la France - Informations [En ligne], Midi-Pyrénées, mis en ligne le 01 mars 1997, consulté le 23 avril 2019. URL : http:// journals.openedition.org/adlfi/10957

Ce document a été généré automatiquement le 23 avril 2019.

(c) Ministère de la Culture et de la Communication, CNRS 


\title{
Toulouse «Tolosa »
}

\author{
Jardin de la basilique Saint-Sernin
}

\section{Christine Dieulafait}

Date de l'opération : 1988 (SD)

Inventeur(s) : Dieulafait Christine

1 Suite à la découverte fortuite, lors de travaux d'adduction d'eau, d'éléments de terre cuite décorée, Quitterie Cazes a partiellement fouillé une fosse située au pied de l'absidiole nord du transept de la basilique Saint-Sernin [ (Fig. $\mathrm{n}^{\circ} 1$ : Localisation des fouilles effectuées dans la ville), plan général, site L].

2 Elle a ainsi recueilli une série de fragments de plaques de terre cuite, ornés de masques humains, feuilles d'acanthe, fleurs et rosaces, appartenant à un décor architectural de style néo-classique datable de la seconde moitié du XVIII ${ }^{\mathrm{e}} \mathrm{s}$.

\section{ANNEXES}


Fig. $\mathrm{n}^{\circ} 1$ : Localisation des fouilles effectuées dans la ville

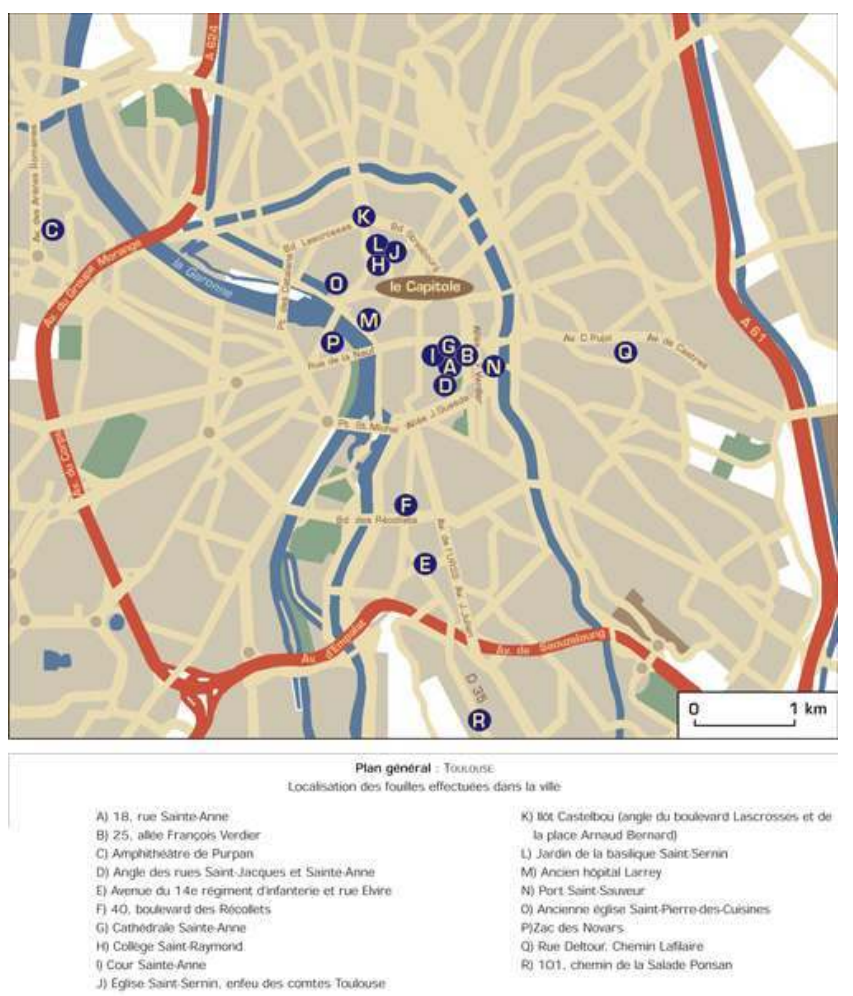

GI 1997 ; CNRS Éditions 1998 (1994)

INDEX

Index chronologique : Temps Modernes

Index géographique : Midi-Pyrénées, Haute-Garonne (31), Toulouse operation Sondage (SD) 